Jurnal Kependudukan Indonesia | Vol. 15 No. 2 Desember 2020 | 227-244

JURNAL KEPENDUDUKAN INDONESIA

p-ISSN: 1907-2902 (Print)

e-ISSN: 2502-8537 (Online)

\title{
STALLED FERTILITY DECLINE IN EAST NUSA TENGGARA, INDONESIA, 2002-2017: UNDERSTANDING ITS DETERMINANTS ${ }^{1}$
}

\section{(PERLAMBATAN PENURUNAN FERTILITAS DI NUSA TENGGARA TIMUR, INDONESIA, 2002-2017: MEMAHAMI DETERMINANNYA)}

\author{
Melianus Mesakh Taebenu \\ Provincial Government of East Nusa Tenggara, Indonesia \\ Correspondence email: mestaebenu@gmail.com
}

\begin{abstract}
Abstrak
Indonesia merupakan salah satu negara yang cukup berhasil dalam mencapai transisi fertilitas. Namun, masih terdapat perbedaan antarprovinsi dengan Nusa Tenggara Timur (NTT) sebagai provinsi dengan Total Fertility Rate (TFR) tertinggi (3,4 kelahiran per wanita) pada tahun 2017. Dengan menggunakan metode analisis dokumen, studi ini bertujuan untuk mengeksplorasi determinan langsung dan tidak langsung dari penurunan fertilitas yang mengalami perlambatan di NTT. Temuan dari studi ini adalah bahwa semua determinan tidak langsung -budaya, sosial ekonomi, dan pemerintahan- telah membentuk perilaku fertilitas yang persisten dari wanita di NTT. Sementara itu, di antara tiga determinan langsungperkawinan, kontrasepsi, dan postpartum infecundability-, kontrasepsi adalah satu-satunya determinan yang bertanggung jawab terhadap perlambatan transisi fertilitas di provinsi ini. Temuan ini menunjukkan bahwa untuk mendorong penurunan tingkat fertilitas di NTT, pemerintah berperan penting dalam meningkatkan penyediaan kontrasepsi, informasi dan pendidikan, serta memberikan insentif untuk memiliki lebih sedikit anak.
\end{abstract}

Kata Kunci: perlambatan penurunan fertilitas, determinan tidak langsung, determinan langsung

\begin{abstract}
Indonesia is one of the countries that has been relatively successful in completing a fertility transition. However, provincial differences in fertility still exist, with East Nusa Tenggara (Nusa Tenggara Timur - NTT) having the highest Total Fertility Rate in 2017 (TFR, 3.4 births per woman). By employing a document analysis method, this study explores the indirect and direct determinants of the stalled fertility decline in NTT. It is revealed that all indirect determinants of fertility culture, socioeconomics, and governance- have shaped women's persistent fertility behaviour in NTT. Meanwhile, among three direct determinants of fertility -marriage, contraception, and postpartum infecundability-, contraception is the only determinant that has been responsible for the stall of fertility transition in this province. These findings suggest that to foster the fertility decline in NTT, the government plays an essential role in boosting the provision of contraception, information and education, and providing incentives for having fewer children.
\end{abstract}

Keywords: stalled fertility decline, indirect determinants, direct determinants

\footnotetext{
${ }^{1}$ This article is a revised version of a research project which was submitted to the Crawford School of Public Policy, Australian National University, in 2019 as part of a Master of Public Policy.
} 


\section{INTRODUCTION}

The twentieth century witnessed a remarkable fertility transition $^{2}{ }^{3}$. Starting in the West, the declining trend in fertility has been followed by Asia, Latin America, and most recently Africa which is also predicted to be completed globally by 2100 (Casterline, 2001; Zhao \& Hayes, 2018). The 2017 Indonesia Demographic and Health Survey (DHS) reported that Indonesia had completed fertility transition (BKKBN et al., 2018). Its Total Fertility Rate (TFR) ${ }^{4}$ was 2.4 births per woman, which almost reached the replacement level fertility (2.1 births per woman $)^{5}$. It is also predicted that Indonesia will be completing the fertility transition by the year 2025 (Seiff, 2014).

Even though the national achievement of fertility transition is undeniable, the fertility differences among provinces in Indonesia are noticeable. A map (Figure 1) illustrates the differences in TFR at the sub-national level in Indonesia.

\section{Figure 1. Total fertility rate by provinces}

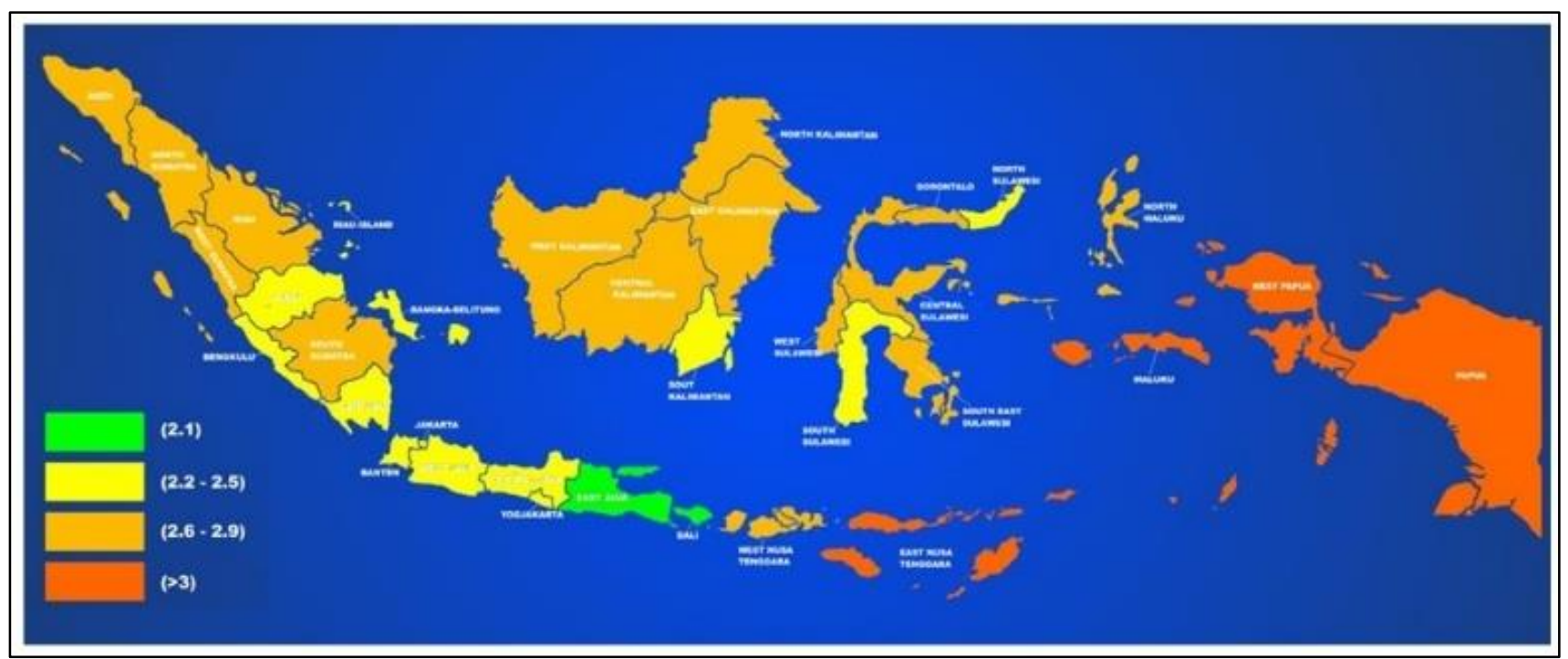

Source: The author's elaboration based on BKKBN et al. (2018)

The map shows that while the other provinces had relatively low TFR, particularly Bali and East Java which has reached the replacement level, some provinces still had high TFR, especially the provinces in eastern Indonesia. In this respect, East Nusa Tenggara (Nusa Tenggara Timur or NTT) was the province in Indonesia with the highest TFR, which was 3.4 in 2017 (Figure 2).

The trend of TFR in NTT has been declining for the last four decades, similar to that of the national TFR.
As shown in Figure 3, in 1970 -the beginning of President Suharto era (1968-1997)- its TFR was roughly as high as the national TFR, around five children per woman. Moving to the end of the era, despite showing a slight upward trend in 1990/1991, the trend of NTT continued to decline, which was similar to the national trend. On average, this province experienced a substantial fertility decline of 2.5 births per woman during the Suharto era.

\footnotetext{
${ }^{2}$ Fertility refers to the number of children born to women (Weeks, 2008). This is a measure of actual reproductive "performance" of women or men, not reproductive "potential" which is alternatively defined in other fields, such as agriculture and medicine.

${ }^{3}$ Fertility transition refers to the shift from high (natural) to low (controlled) birth rate (Weeks, 2008, p. 199).
}

${ }^{4}$ TFR estimates "the average number of children that a woman would bear if she were to pass through all her childbearing years conforming to the age-specific fertility rates of a given year" (Preston et al., 2000, p. 95).

${ }^{5}$ The level of fertility needed for a population to replace itself (Preston et al., 2001). Recently, the ideal TFR is at 2.1 (UN, 2014). 
Figure 2. Fertility differences among provinces in Indonesia, 2017

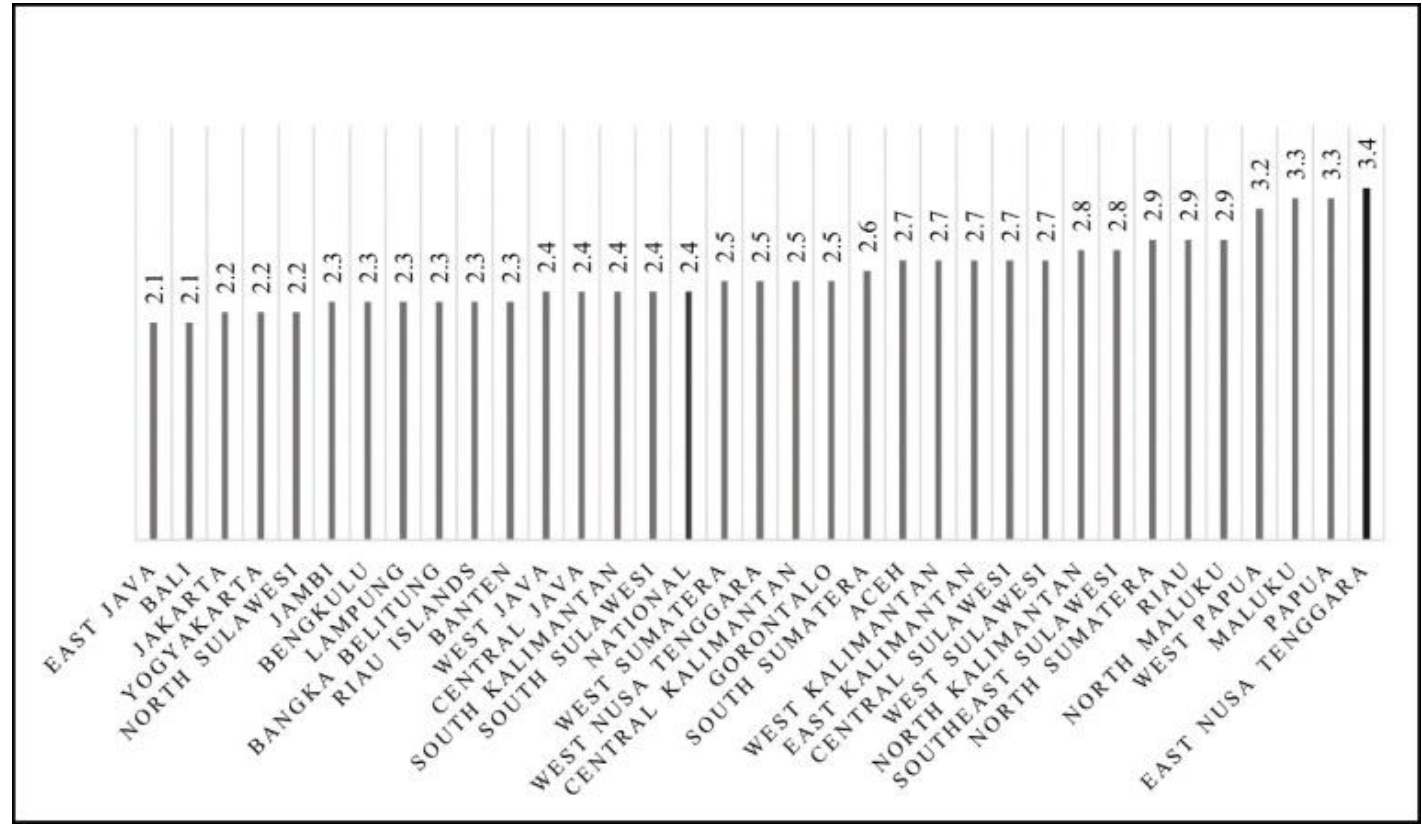

Source: The author's elaboration based on BKKBN et al. (2018)

Figure 3. TFR of East Nusa Tenggara and Indonesia, 1970-2017

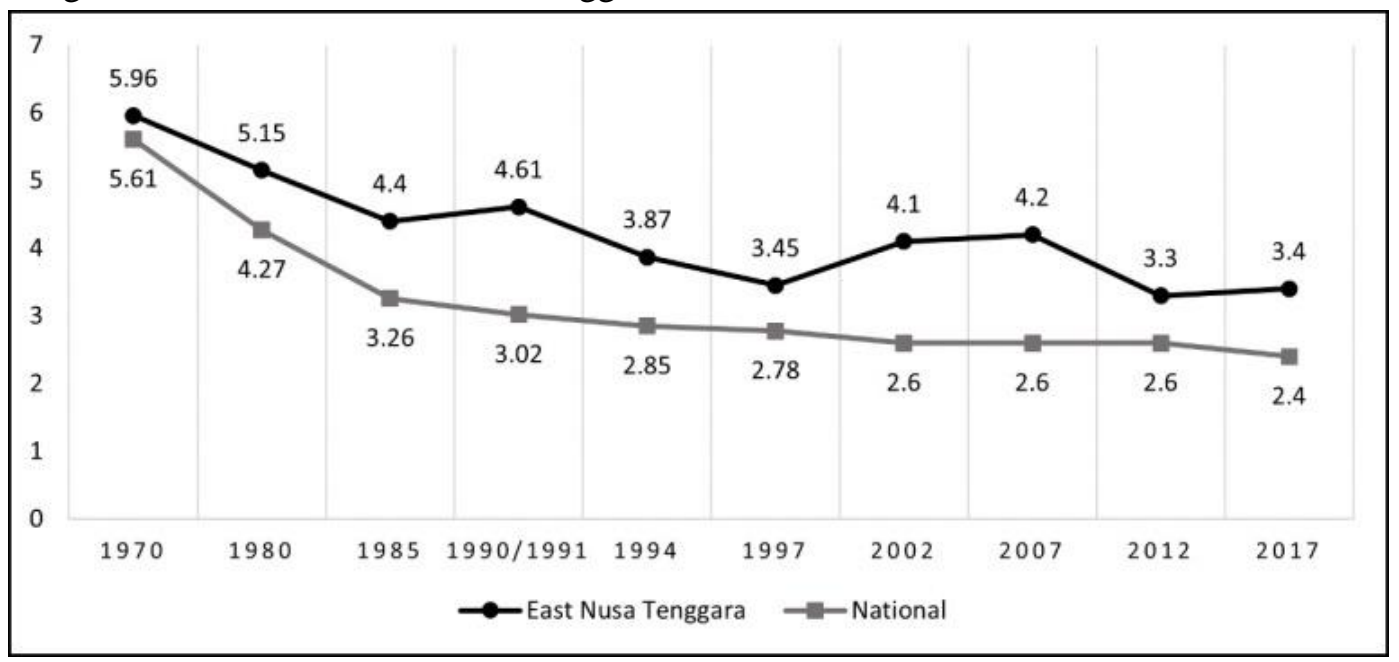

Source: The author's elaboration based on BKKBN et al. (2018)

While the national TFR has continued to decrease the post-Suharto era -the so-called the decentralisation era (officially established since January 2001) - NTT has shown a slightly different trend. In 2002 the TFR was 4.1 and peaked in 2007 to 4.2 births per woman. In 2017 it dropped again to 3.4 births per woman. The stalled fertility decline in NTT from 2002 to 2017 makes its TFR has remained the highest in Indonesia and has been still relatively far to the replacement level.

The stalled fertility decline phenomenon in NTT is crucial. On the one hand, this province has been underperforming in many socio-economic indicators categorising it as one of the least developed provinces in Indonesia. For instance, in 2015, it ranked first out of 33 provinces in Indonesia regarding the highest dependency ratio (66.7) (Ritonga, 2014). Concerning poverty, in 2018, 21.03 per cent of its population was categorised as the poor, making this province had the third-highest rate of poverty nationally (Statistics Indonesia, 2018). Its Human Development Index (HDI) rank was also the third-lowest among the provinces in 2018, 64.39, compared to 71.39 nationally (Statistics Indonesia, 2018). 
On the other hand, fertility decline and the socioeconomic aspects tend to reinforce each other in a vicious circle (Birdsall \& Sinding, 2001). For instance, in terms of education, the stalled fertility decline might contribute to the stagnation of the improvement in education outcomes in NTT, and vice versa. Having many children increases women's opportunity cost to prolong their participation in schools because they need to spend more time on both childbearing and childrearing responsibilities. The other way around, women with low quality of education might find it difficult to control the timing and spacing of births and the number of children they wanted to have. This gets complicated because there are persistent cultural factors, such as bride price practices in marriages, the high value of children to parents, and strong patriarchal norms, that might shape individuals' reproductive behaviour in NTT (Koten, 2015; Setiawan, 2005). Therefore, a rapid fertility decline to the replacement level might partially improve the socio-economic outcomes so that society's wellbeing in this province might be better off.

Many scholars have explored the determinants of stalls in fertility decline in various settings in the world. It was found that the stall in fertility decline in four Eastern African countries over the past 20 years were attributable to increased unmet need for family planning, preferences for larger families, adolescent fertility, and declined contraceptive use (Ezeh et al., 2009). Meanwhile, by using DHS data from 47 developing countries, including Indonesia, Kreider et al. (2009) revealed that the pace of the countries' decline was varied. However, eight countries in subSaharan Africa (SSA) experienced substantial stalls in fertility transitions due to inadequate education, health, and family planning services. In Bangladesh, Rahman (2019) studied two fertility stalls, 1996-2000 and 1996-2000, that appeared in the country and found that contraceptive use and induced abortion were primarily associated with the stalls. Whereas, when examining the determinants of the fertility decline in Indonesia between 2002-03 and 2012 that was stalled at 2.6 children per woman, Kumar (2016) discovered that the stall resulted from the reductions in breastfeeding durations.

While many studies have explored various determinants of stalled fertility declines at the national levels in many countries, there is a dearth of research explaining the stall in the sub-national levels in Indonesia, including NTT. Hence, this study predominantly explores the indirect and direct determinants of the stalled fertility decline in NTT. This study hopes to enrich the theoretical explanations of the stalled fertility decline in the sub-national levels like NTT and suggest future research in similar areas. Empirically, this study's result might serve as the justification for policy implications of the stalled fertility declines in the studied region.

\section{METHODOLOGY}

Document analysis is conducted in this study. Document analysis is a qualitative research method employed to review or evaluate documents "to elicit meaning, gain understanding, and develop empirical knowledge" (Bowen, 2009, p. 27). The primary sources of documents used to discover the stalled fertility decline determinants in NTT are the Indonesia DHS between 1991 and 2017. It is supported by other documents, such as published reports, books, journal articles, and media outputs. The analysis process in this study includes finding, selecting, appraising (making sense of), and synthesising data in the documents with the assistance of graphs, following by interpreting the data to conclude (Bowen, 2009, p. 28). Nonetheless, as this study's nature is a qualitative inquiry, the analysis is not utilised any inferential statistical technique or tool. Therefore, in uncovering the relationship between the determinants and the state of the stalled fertility decline in NTT, it is based on the researcher's interpretation.

This study also employs an analytical framework (shown in Figure 4) to explain changes in the course of fertility transition and the determinants underlying it. The framework is blended from the framework of Bongaarts $(1978,1982)$ and Hull (1987). It is shown that indirect determinants of fertility trend include culture, socioeconomics, and governance. These indirect determinants are chosen to be embedded in the framework because they are considered to be most closely linked to the studied region's characteristics. To gain more focus, the cultural determinant is analysed through the value of children and bride price in NTT. Moreover, women's educational attainment and labour force participation are used to analyse the socio- 
economic rationale for fertility. Meanwhile, regarding governance factors, this study concentrates on the role of government as well as foreign bodies in promoting the anti-natalist policy -family planning-in the studied region.

Figure 4. The analytical framework of determinants and outcomes of fertility

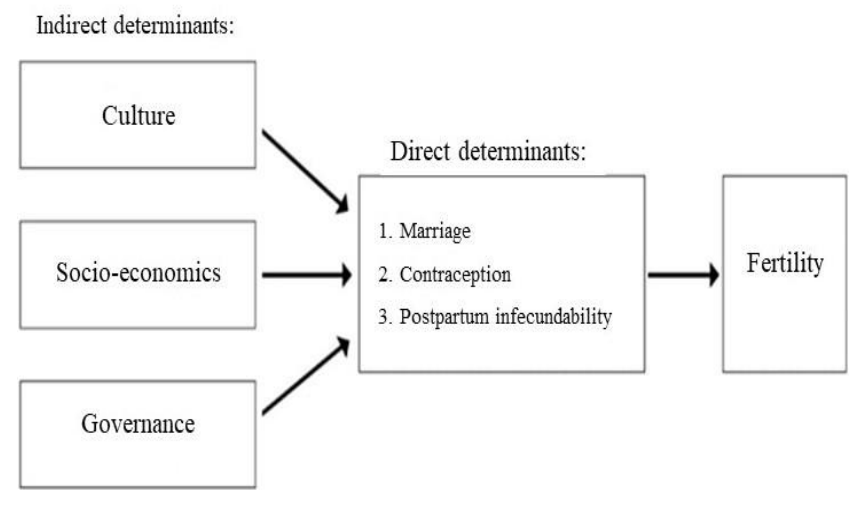

Source: The author's elaboration based on Bongaarts (1978, 1982) \& Hull (1987)

essential to bear this point in mind that these determinants do not work in a simple fashion. Proximate determinants directly determine any level or change of fertility in any given setting. Therefore, this study utilises the proximate determinants proposed by Bongaarts (1982). However, of the seven determinants ${ }^{6}$, only three determinants -marriage, contraception, postpartum infecundability- are chosen to be used as the lens in this study. They are considered to be most relevant to the dynamics in NTT and due to the availability of the data.

\section{INDIRECT DETERMINANTS}

\section{Cultural Determinants}

The value of children and bride price is the most prominent cultural factors shaping fertility behaviour among individuals in NTT. The empirical results in this study reveal the importance of children's value in explaining the patterns of declining birth rates in NTT.

As summarised in Figure 5, fertility outcomes in this province over the last two decades were associated with values attributed to children. The decreasing trend of fertility in NTT had between 2002 and 2017. Mean while, the mean ideal number of children for evermarried women age 15-49 had also shown a similar pattern. Moreover, it is still far behind in comparison to the other provinces in Indonesia in the period.

Figure 5. Mean ideal number of children for evermarried women age 15-49 and Total Fertility Rate of East Nusa Tenggara and Indonesia, 1997-2017

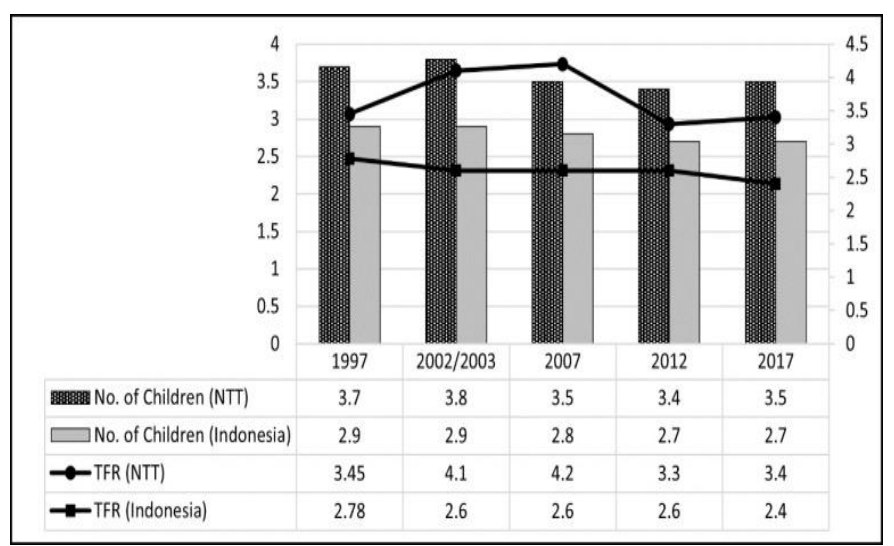

Source: The author's elaboration based on Statistics Indonesia et al. (1998, 2013), Statistics Indonesia and ORC Macro (2003), Statistics Indonesia and Macro International (2008), and BKKBN et al. (2018)

In Figure 6, it can also be seen obviously that among provinces in Indonesia, NTT had the second highest mean ideal number of children in 2017. While the average women in other provinces preferred to have 2.7 children during their lifetime, those in NTT still desired to bear an average of 3.5 children.

\footnotetext{
${ }^{6}$ These include: 1) Proportion married among females, 2) Contraception use and effectiveness, 3) Prevalence of induced abortion, 4) Duration of postpartum infecundability,
}

5) Fecundability (or frequency of intercourse), 6) Spontaneous intrauterine mortality, and 7) Prevalence of permanent sterility. 
Figure 6. Mean ideal number of children for ever-married women age 15-49 by provinces, 2017

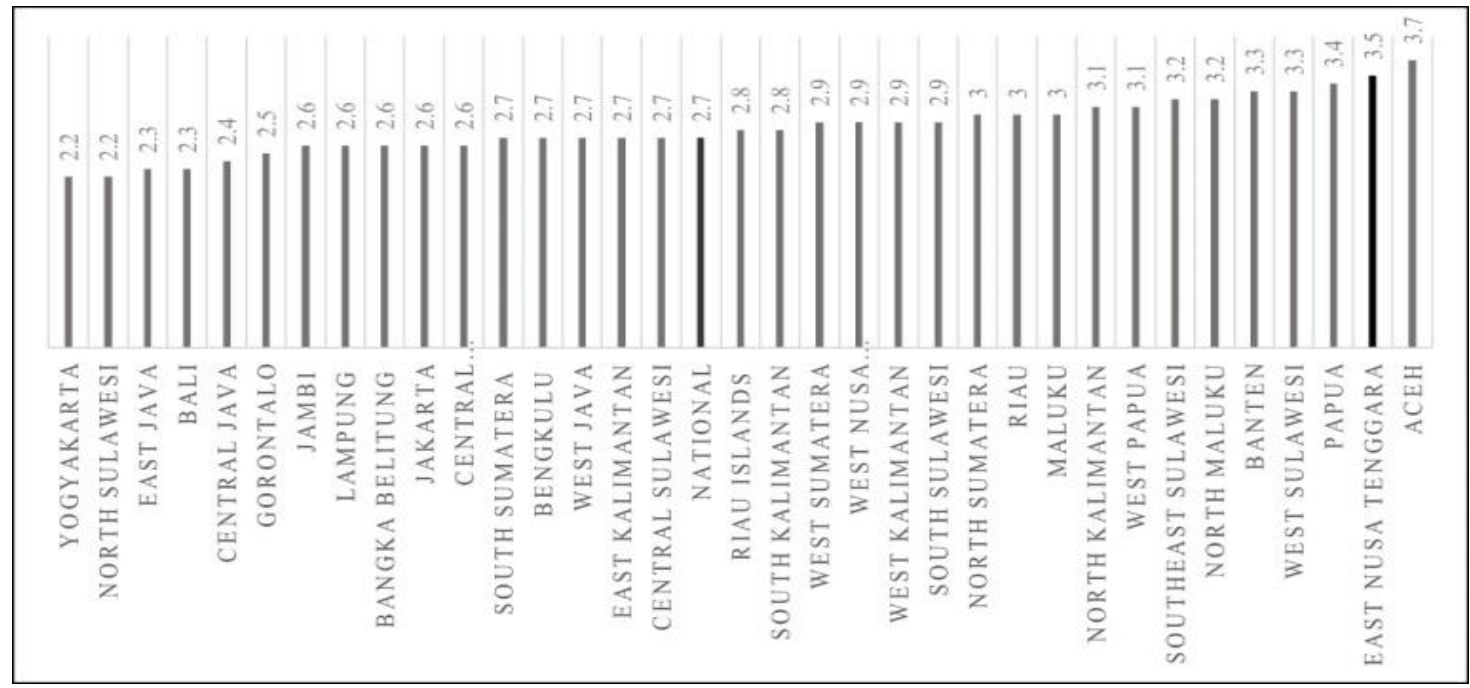

Source: The author's elaboration based on BKKBN et al. (2018)

These data highlight that individuals in this province still value children highly compared to the other provinces over the last two decades. These findings are also consistent with previous studies (Bria, 2014; Koten, 2015). It was found that individuals' high fertility desires are probably attributable to the persistent traditional family norm (large family size) among individuals in this province. Therefore, children's value is one of the cultural determinants that shape individuals' persistent reproductive behaviour in this province for the last two decades.

Another critical cultural factor discussed is the bride price. Bride price refers to a symbolic form of dowry given by the groom's family to the bride's family as a marriage condition (Rodliyah et al., 2016, p. 26). The bride price provisions in a marriage apply in some tribes in Indonesia (Kurniawan, 2019). NTT is one of the provinces where most tribes apply a relatively high bride price (known as belis) in marriages that may take the form of money, livestock, or goods, such as metal ornaments and elephant ivory (Fillaili \& Mawardi, 2006, p. 25). The higher the bride's social status and education level, the higher the bride price that must be paid by the groom's family, which can reach IDR 500 million or equal to USD 34,353 (Wonga, 2017).

Setiawan (2005) suggested that the tradition of paying a bride price prevailing in NTT can be understood as a form of appreciation for a bride because she will play a wife who will accompany her husband to manage their household. She will also become a mother who gives birth to family continuity. The bride price can also be seen as a form of appreciation for a bride's families, especially her parents, who have raised her.

Although there are strong cultural reasons for maintaining the bride price, this tradition places a heavy economic burden on families in NTT (Fillaili \& Mawardi, 2006, p. 27). While the average per capita income in the province is relatively low and around onefifth of individuals in NTT are the poor (Statistics of NTT Province, 2017), a large amount of money is needed by the groom's family to get married. Consequently, the groom's parents tend to choose to have many children so that the children can help to reduce the economic burden of their parents to pay the price.

The bride price also has implications for gender relations at the household level (Fillaili \& Mawardi, 2006; Setiawan, 2005). Due to a wife being "bought in full payment" in the form of bride price, a husband and his extended family, tends to be very dominant in the household, including making decisions about the ideal number of children and sex ratio. That is, bride price places a heavy burden on a woman after marriage in which she must be able to give birth; otherwise, she might get social sanctions from her husband's family. Moreover, she is expected to bear many children with an ideal sex ratio. Therefore, the bride price's continued existence is strongly associated with the persistent relative high fertility attitudes of female individuals in this province. 


\section{Socio-economic Determinants}

Another important indirect determinant of the trend of women's fertility behaviour is their socio-economic conditions. This study assessed this determinant by examining educational attainment and labour force participation of women. Regarding educational attainment, it is argued that female education has a negative relationship with fertility (Easterlin, 1975; Weeks, 2008). A woman who stays longer in school can prolong the age of first marriage and shorten her reproductive period. Moreover, a more educated woman is likely to have more knowledge regarding reproductive behaviour and its outcomes and control births. They can also gain more information about prenatal and childcare, so the risks of infant deaths can be reduced. Therefore, high educational levels of women can result in low demand and supply of children resulting in a low fertility rate.

The empirical results of this study reveal the association between education and fertility. As shown in Figure 7, between 2002 and 2017, there was a notable increase in women's median years of schooling in NTT. In terms of literacy of women, Figure 8 also shows a similar trend during this period. These findings may also indicate that female education in NTT is still far behind compared to the other provinces in Indonesia.

Figure 7. Women's median years of schooling and Total Fertility Rate of East Nusa Tenggara and Indonesia, 1997-2017

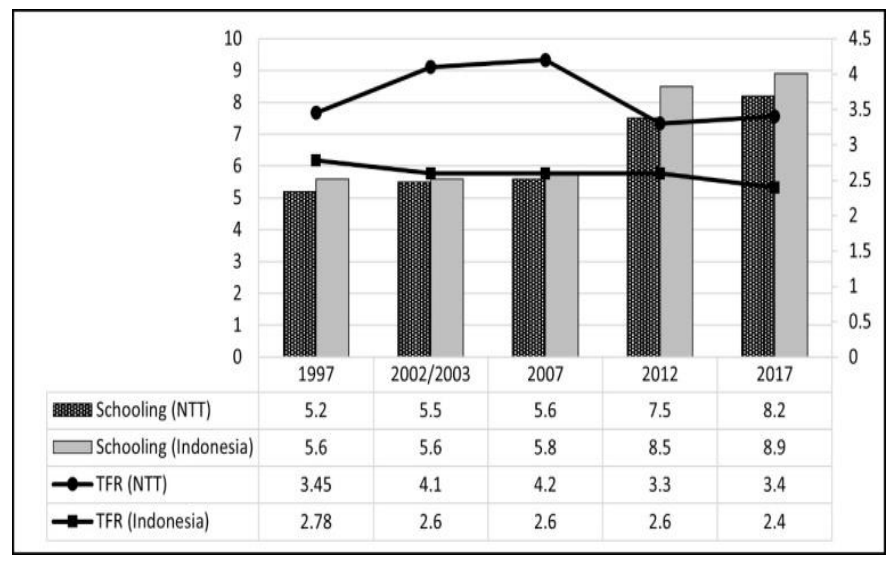

Source: The author's elaboration based on Statistics Indonesia et al. (1998, 2013), Statistics Indonesia and ORC Macro (2003), Statistics Indonesia and Macro International (2008), and BKKBN et al. (2018)
Figure 8. Women's literacy and Total Fertility Rate of East Nusa Tenggara and Indonesia, 2002/2003-2017

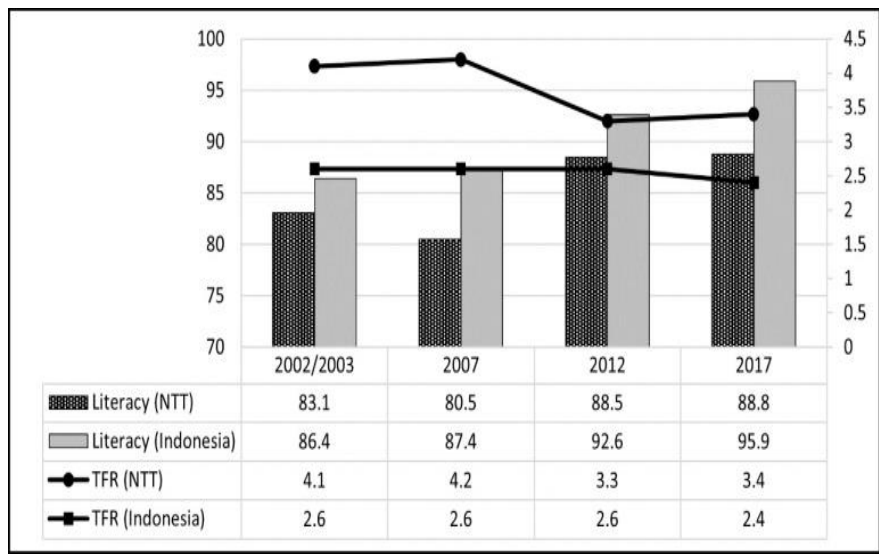

Source: The author's elaboration based on Statistics Indonesia et al. (1998, 2013), Statistics Indonesia and ORC Macro (2003), Statistics Indonesia and Macro International (2008), and BKKBN et al. (2018)

In 2017, the Indonesia DHS reported that the median female years of schooling in NTT, together with Papua and West Kalimantan were still 8.2 while figures from other provinces were much above it (BKKBN et al., 2018 , p. 259). This province also registered as the second-lowest among provinces in Indonesia regarding literacy of women (BKKBN et al., 2018, p. 261). It also reveals that 4.6 per cent of women in this province still had no education in 2017 while in other provinces with low TFR, such as North Sulawesi (2.2), 0 per cent of women with no education (BKKBN et al., 2018, p. 259).

Even though female education in NTT has been promoted between 2002 and 2017, it can be argued that the low level of female education indirectly shapes the persistent relatively high level of fertility in the studied region during this period in NTT in comparison to the other provinces in Indonesia.

Another aspect of the socio-economic determinants assessed in this study is women's opportunities in the labour market. It is argued that the course of fertility transition is commensurate to the increasing opportunities for women, including their participation in the labour market (McDonald, 2000, p. 432). That is, fertility and female labour force participation reinforce each other. When fertility decreases (i.e., women have fewer children on average), women can have more opportunities to pursue paid employment outside the 
family cycle. Conversely, by devoting more time in the labour market, they can have higher opportunity costs of bearing children respective of their income earnings and consequently desire fewer children.

This study's empirical findings reveal that women in NTT had a constant decreasing opportunity in the labour market from 2002 to 2017. There was an increasing trend at the national level until 2007 before bouncing back in the following years (Figure 9). The decreasing share of women's participation in the labour market decreases the opportunity cost of having many children. They can devote most of their time on both childbearing and childrearing activities. By having many children, conversely, they will have a smaller opportunity to go into the labour market due to childbearing and childrearing responsibilities. As a result, high female unemployment shapes women's fertility behaviour in NTT over the last two decades.

Figure 9 also exposes the share proportion of women in NTT in the labour market that was slightly higher than the national average during 2002-2017. However, it is also found that the share proportion of women employed in this province was still far lower than those of provinces with low TFR. In 2017, for instance, the share proportion of women employed in Yogyakarta and Bali were 67.9 and 78.4 per cent consecutively, while in NTT, it was only 54.6 per cent (BKKBN et al., 2018, p. 267). Other than that, although more women in NTT have already entered the labour force in comparison to the other women in the most provinces, most of the women in this province are working in informal sectors, in particular, subsistence agriculture (43.6 per cent) (BKKBN et al., 2018, p. 269). In this type of farming, simple tools are used to grow crops. Many labours are also needed to do it. However, paying additional labours can be uneconomical for them. Consequently, this condition also shapes the value of children. By having many children, women working in subsistence agriculture can be helped by the children to do agricultural activities or other work, such as collecting firewood from the forest and fetching water from wells. Therefore, the low opportunity of female workers in the labour market had shaped the persistent fertility behaviour in this province.
Figure 9. The distribution of women age 15-49 by employment status and Total Fertility Rate of East Nusa Tenggara and Indonesia, 1997-2017

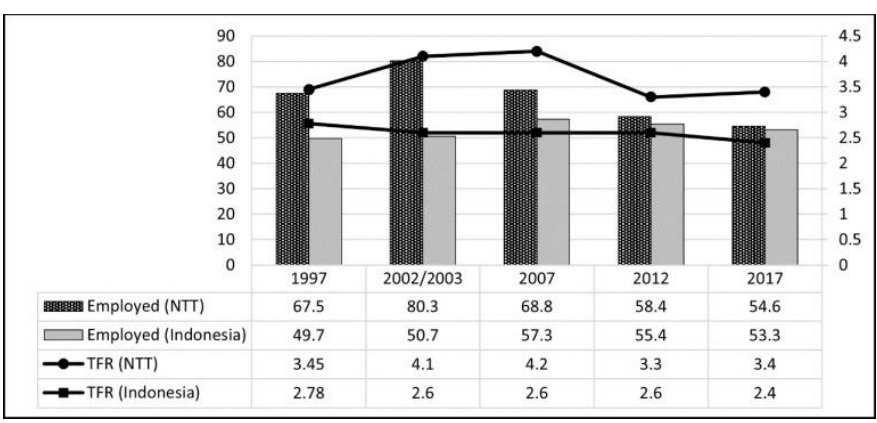

Source: The author's elaboration based on Statistics Indonesia et al. (1998, 2013), Statistics Indonesia and ORC Macro (2003), Statistics Indonesia and Macro International (2008), and BKKBN et al. (2018)

\section{Governance Determinants}

Governance factors also play an essential role in influencing the fertility behaviour of individuals through relevant natalist policy. In a country with low fertility, by promoting pro-natalist policies, such as childcare provision and the baby bonus, women will have greater incentives to have more babies resulting in the reverse trend of low fertility (Bongaarts \& Sobotka, 2012; McDonald \& Moyle, 2010). This phenomenon has been recently recorded in some western countries. Meanwhile, a country where the fertility is high, when the government promotes anti-natalist policies, such as through the provision of sufficient information and access to control births, lower fertility rate can be established, which has also been the case for most countries in the world (Gietel-basten, 2018; Weeks, 2008).

In Indonesia, many scholars have found that the role of governance has been substantial to lower fertility, in particular during the regime of President Suharto through the national Family Planning program coordinated by the National Family Planning Coordinating Board (also known by its Indonesian initials BKKBN) (Hull, 1987, 2007; Permana and Westoff, 1999; Cammack and Heaton, 2001; Hull and Hartanto, 2009). However, the program has not seen as successful as in Suharto's period after he was removed from leadership following the onset of an economic and political crisis in 1997. 
With Suharto resignation, the program's support has decreased significantly (Hull \& Mosley, 2009). Under a new governance system -decentralisation-, BKKBN, which was previously supported by the president and various stakeholders, has been forced to promote the family planning policy. It has been found that some agencies at the national level have implemented policies that are less synchronous with those of BKKBN (Oktriyanto, 2016). For instance, BPJS -an agency that administers the Indonesian national health insuranceprovides health insurance up to the third child of its members which is not synchronous with the two-child norm campaigned by BKKBN. Moreover, most religious organisations that tended to be forced by President Suharto to successful family planning program have backtracked (Hull, 2007, p. 244). They are now campaigning against birth controls and proclaiming that using modern contraceptive methods is sinful.

After having more significant autonomy in managing governmental affairs at the local levels, local governments tend not to prioritise demographic affairs, including fertility, into their main agendas. It is not considered strategic for local leaders and most managers due to its long-term impacts. Consequently, many family planning agencies have been merged into other agencies (Hull \& Mosley, 2009, p. 37). In NTT, the responsibility for family planning has been transferred to other government agencies, such as women empowerment agency (in Ende regency) and civil registration agency (in Ngada regency) (Rahmadewi \& Asih, 2011).

Other than that, in most local governments in Indonesia, many Family Planning field workers have been transferred to other government agencies that are not related to family planning (Hull \& Mosley, 2009, p. 37). In NTT, it was found that under decentralisation, the ratio of family planning field workers and the clients had widened, compared to other provinces (Rahmadewi \& Asih, 2011). While a field worker in the other provinces, such as Yogyakarta, provides services for the clients in two villages, a field worker in NTT manages more than five villages. In some extreme cases, a field worker has to look after up to twenty villages, such as Central Sumba regency. This phenomenon gets complicated because the geographical terrain of NTT and limited infrastructure have impeded a local family planning field worker's ability to reach out to many remote villages.

These challenges have also been aggravated by the shifting focus of international donor communities for family planning programs from Asian countries to African countries (Hull \& Mosley, 2009, p. 37). For instance, USAID gradually started to phase out Indonesia's support in 2003 and terminated it entirely in 2006. As a result, strategic, financial, and technical supports from one of the major donors for family planning in Indonesia have been significantly reduced, and NTT felt the full brunt of this compared to other provinces.

\section{DIRECT DETERMINANTS}

\section{Marriage}

Age at first marriage of women is one of the main direct determinants of fertility. It is argued that the younger the age at first marriage, the greater the risk of being exposed to pregnancy (Bongaarts, 1982). In many settings, it has been found that during fertility transition, the increasing age at first marriage has significantly impacted the decreasing trend of TFR (Atieno, 2012; Murigi, 2016; Tey et al., 2012).

However, this study's empirical findings reveal that between 2002 and 2017, the increasing trend of the median age at first marriage among women and its impact on the decreasing trend of TFR in NTT had been less associated. Figure 10 shows that while the fertility decline had stalled between 2002 and 2017, the median age at first marriage among women in NTT had increased. It had also been far higher than that of the national average during the period. In the latest survey, 2017, the median age at first marriage among women in NTT was 22.5, which was higher than the national average (20.8). Even, it was higher than other provinces with low TFR, such as East Java (20.4) and Bali (22.1) (Figure 11). 
Figure 10. The median age at first marriage among women and Total Fertility Rate of East Nusa Tenggara and Indonesia, 1997-2017

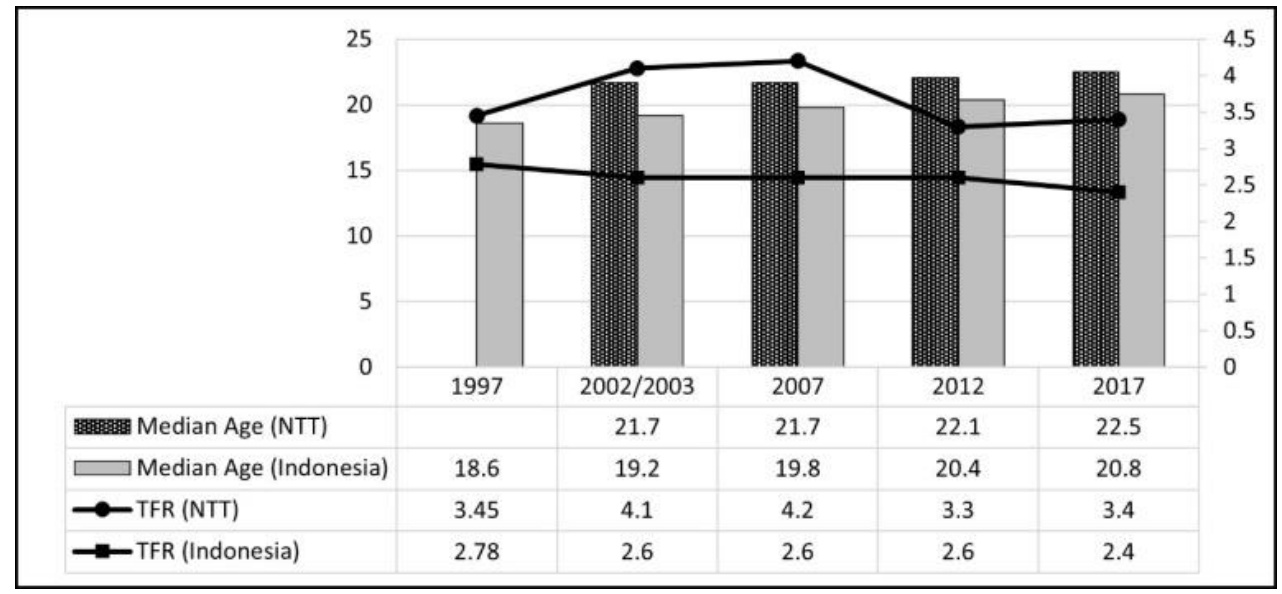

Source: The author's elaboration based on Statistics Indonesia et al. (1998, 2013), Statistics Indonesia and ORC Macro (2003), Statistics Indonesia and Macro International (2008), and BKKBN et al. (2018)

Figure 11. The median age at first marriage among women by provinces, 2017

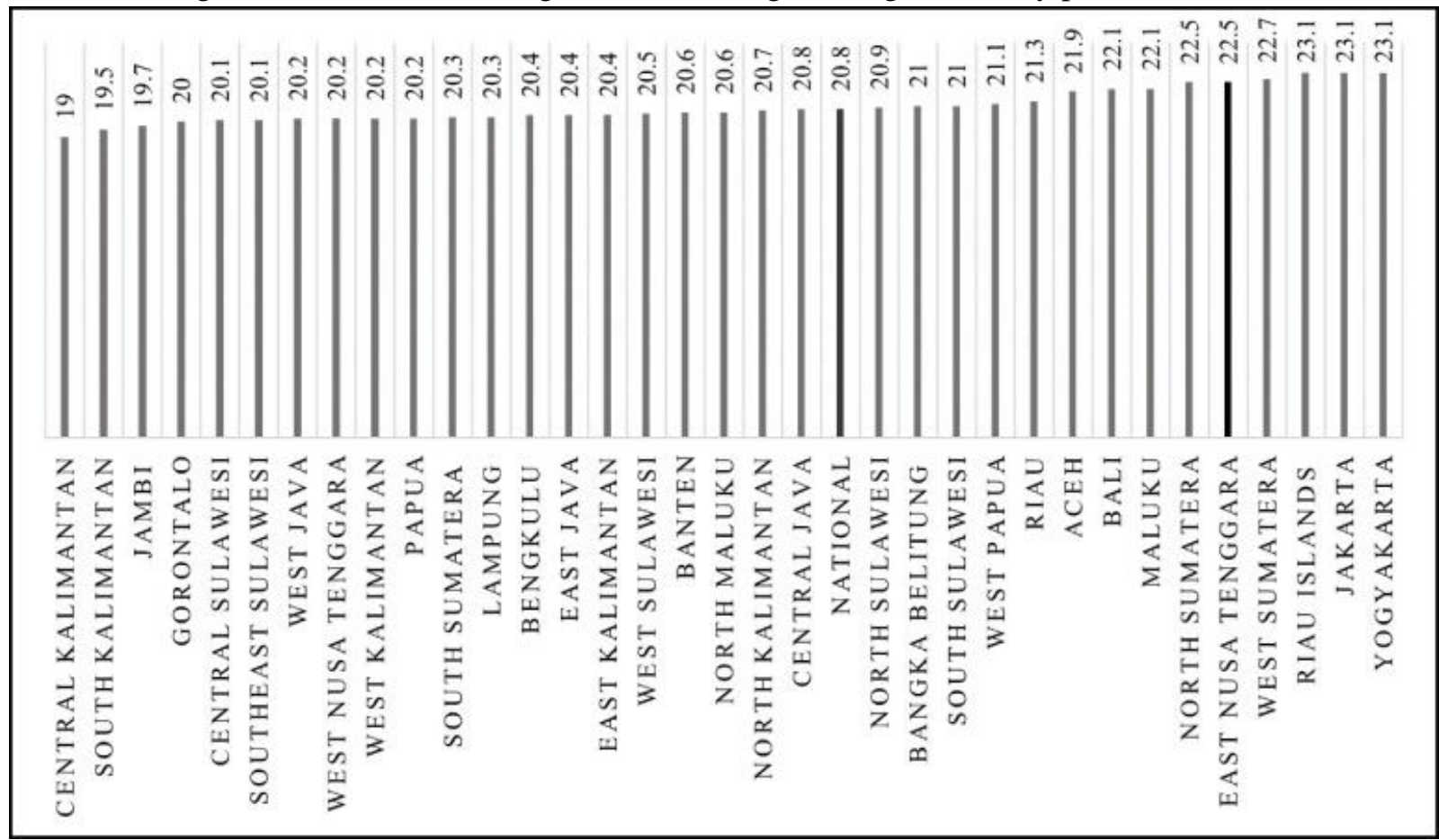

Source: The author's elaboration based on Statistics Indonesia et al. (1998, 2013), Statistics Indonesia and ORC Macro (2003), Statistics Indonesia and Macro International (2008), and BKKBN et al. (2018)

Several studies conducted to explore this phenomenon have found that the high median age at first marriage among women in NTT is partly due to the high bride price in marriage (Hull et al., 1999; Rahmadewi \& Asih, 2011; Setiawan, 2005). Generally, couples in NTT need to follow three phases of marriage. It begins with a traditional marriage followed by church marriage and legally registered marriage. However, before the traditional marriage is carried out, a groom and his family must pay the bride's price for the bride's family (Hull, 1999, p. 48). On the one hand, an inability to afford the price raises social sanctions, such as sarcasm and social exclusion, against the groom and his family. 
On the other hand, it is commonly found that bride price payments are relatively high, compared to the economic readiness of the groom. This makes a woman in NTT prolong her age waiting for her man to be ready economically, mostly in his mid-twenties, to pay the bride price before entering the marriage (BKKBN et al., 2018, p. 276; Rahmadewi \& Asih, 2011, p. 122). Therefore, it can be argued that unlike in the other settings in which decreasing trend of fertility is highly associated with the increasing median age at first marriage among women, in the case of NTT, the persistent fertility rate might be less associated with the median age at first marriage.

\section{Contraception}

Another direct determinant of fertility discussed in this study is contraception. Contraceptive use, in particular, modern methods of contraceptives, is the primary direct determinant in lowering fertility (Bongaarts, 1982). When more individuals, particularly women, utilise contraceptive methods effectively to control the timing and spacing of births and the number of children they desire, more births can be averted, resulting in the decreasing fertility rate. Since the adoption of contraceptive methods globally, many scholars have conducted studies in various settings and found that contraceptive use has been the most direct determinant of fertility (Abbasi-Shavazi et al., 2009; Hull, 2007; Jatmiko \& Wahyuni, 2019; Majumder \& Ram, 2015; Sibanda et al., 2003).

The empirical results in this study show that contraception is crucial to promote fertility decline (Figure 12). In 1997, when 39.3 per cent of women used contraceptives to control births, the TFR in this province reached 3.45. However, when the prevalence of contraceptive use decreased in 2002/2003 to 34.8, the TFR was also increasing and reached a peak in 2007. In 2017, when the proportion of women using contraceptive was only around a third of the total, which was almost similar to the proportion in 1997, the TFR of this province in 2017 remained relatively high, 3.4 , which was almost similar to the initial condition in 1997. Therefore, it can be argued that the stalled contraceptive use had been the primary direct determinant of the stalled fertility decline in NTT between 2002 and 2017.
Figure 12. Contraceptive use and Total Fertility Rate of East Nusa Tenggara and Indonesia, 1997-2017

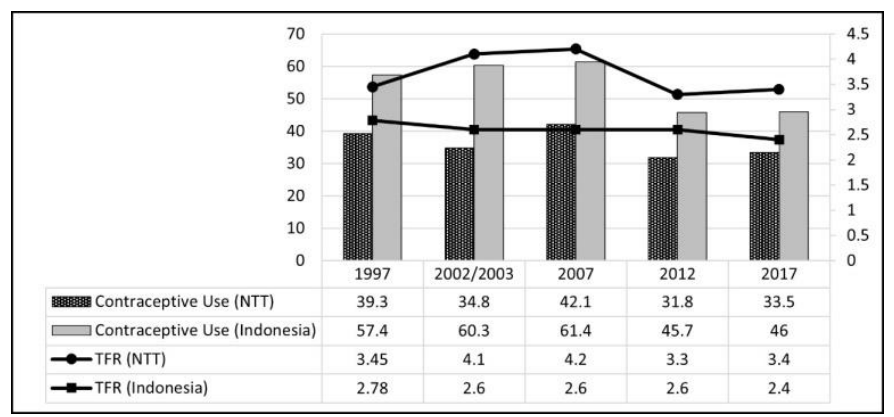

Source: The author's elaboration based on Statistics Indonesia et al. (1998, 2013), Statistics Indonesia and ORC Macro (2003), Statistics Indonesia and Macro International (2008), and BKKBN et al. (2018)

Another finding that emerged in this study is that the supply side (Figure 13) and the demand side (Figure 14) of contraceptive use in NTT are the poorest among provinces from 2002 to 2017. In 2017, the Indonesia DHS reveals that the demand for contraceptive use in NTT was the fifth-lowest among provinces (BKKBN et al., 2018, p. 293). While 74.2 per cent of women in Indonesia required contraceptive use to control births, only 67.7 per cent of women in NTT wanted to control births by utilising contraceptives.

Figure 13. Demand for family planning and Total Fertility Rate of East Nusa Tenggara and Indonesia, 1997-2017

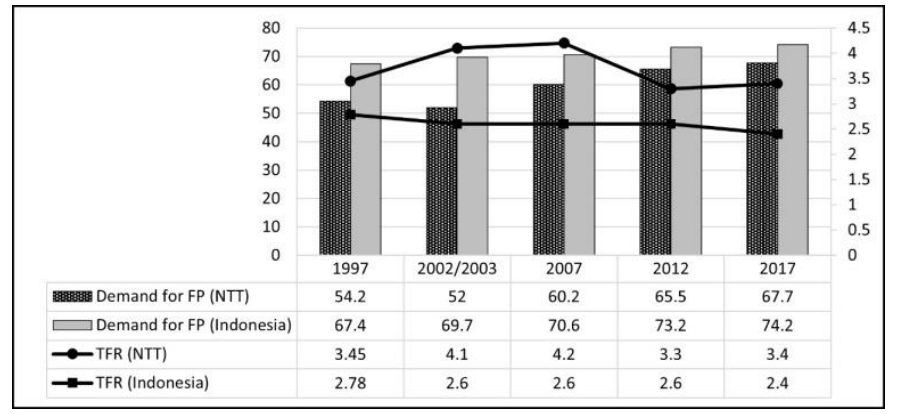

Source: The author's elaboration based on Statistics Indonesia et al. (1998, 2013), Statistics Indonesia and ORC Macro (2003), Statistics Indonesia and Macro International (2008), and BKKBN et al. (2018) 
Figure 14. Unmet need for contraception and Total Fertility Rate of East Nusa Tenggara and Indonesia, 1997-2017

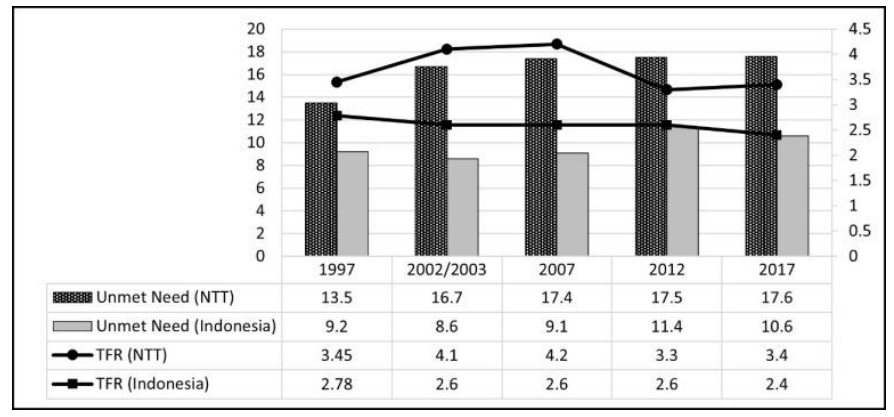

Source: The author's elaboration based on Statistics Indonesia et al. (1998, 2013), Statistics Indonesia and ORC Macro (2003), Statistics Indonesia and Macro International (2008), and BKKBN et al. (2018)

Some scholars argued that children's high value drives the low demand for contraceptive use among women in this province among families (Bria, 2014; Koten, 2015). Even though the median age at first marriage among women is relatively high, resulting from the bride price tradition, once having entered marriage, they will bear many children to fulfil the desire to have many children. Another factor shaping the use of contraception in this province is the socio-economic conditions of women. The low education of women in this province makes them have less knowledge to use contraceptive methods effectively. For instance, as Rahmadewi \& Asih (2011, p.120) found, several women who were still in the reproductive age (under 45 years), decided not to use contraceptive methods anymore because they assumed that they had entered menopause. The other socio-economic factor is the limited opportunity of women in the labour market. This makes them have less opportunity cost in childbearing and childrearing, resulting in less demanding contraception to control births.

In 2017, the Indonesia DHS also reveals that unmet need ${ }^{7}$ for couples being voluntary use contraceptive methods to control births in NTT was the secondhighest among provinces in 2017 (BKKBN et al., 2018, p. 293). While women in other provinces can easily

\footnotetext{
${ }^{7}$ Unmet need for family planning denotes "the proportion of women who (1) are not pregnant and not postpartum amenorrhoeic and are considered fecund and want to postpone their next birth for 2 or more years or stop childbearing altogether but are not using a contraceptive
}

access contraceptive methods, those in NTT found it challenging to get them even though they wanted to control births. This condition is mainly associated with the role of government. It has been found that the imbalance of family planning clinics between Western and Eastern Indonesia has posed a barrier for couples of childbearing age, including in NTT, to access contraceptive methods (Rahmadewi \& Asih, 2011). Other than that, this is also associated with severe geographical conditions with poor infrastructure in this area. Individuals have difficulty to reach the clinics provided.

Therefore, it is evident that the role of contraception is crucial in shaping fertility attitudes of women. In a setting with a high prevalence of contraceptive use, the TFR is low, and vice versa. The role of government in promoting information and education to motivate couples to utilise contraceptive methods and provide services widely and affordably for contraception is essential to promote fertility transition in such settings, including in NTT.

\section{Postpartum infecundability}

Postpartum infecundability is the third direct determinant of the stalled fertility decline assessed in this study. Postpartum infecundability measures the effects on fertility of the extended period of postpartum amenorrhea (breastfeeding) and postpartum abstinence (sexual abstinence) (Bongaarts, 1982). The longer the median number of months of breastfeeding and sexual abstinence after the birth of a child leads to a more extended period of ovarian inactivity to becoming pregnant, which lowers fertility. Several studies were conducted to measure the effect of postpartum infecundability toward fertility. Kumar (2016), when conducting his study on Indonesia's late fertility transition stall, found that the reduction of postpartum amenorrhea was the major cause of the stall. Meanwhile, in Uganda, Rutaremwa et al. (2015) found that apart from contraceptive use and marriage, postpartum infecundability had also contributed to the

method, or (2) have a mistimed or unwanted current pregnancy, or (3) are postpartum amenorrhoeic and their last birth in the last 2 years was mistimed or unwanted" (BKKBN et al., 2018, p. 95). 
differences in fertility attitudes among women in this country.

The finding emerged in this study, as shown in Graph 13 , reveals that the median number of months of breastfeeding and postpartum abstinence among women in NTT during the period between 2002 and 2017 had been higher than that of women in the other parts of Indonesia. However, postpartum infecundability had likely been not associated with the stall of fertility decline in this province.

Figure 15. The median duration of postpartum infecundability and Total Fertility Rate of East Nusa Tenggara and Indonesia, 19972017

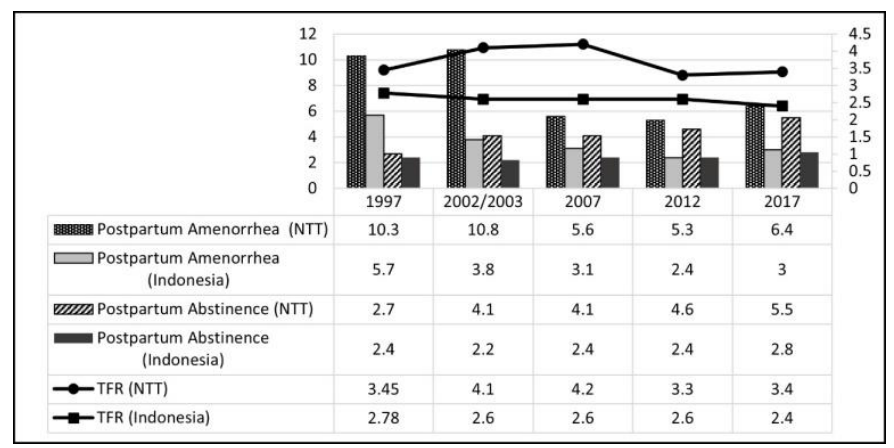

Source: The author's elaboration based on Statistics Indonesia et al. (1998, 2013), Statistics Indonesia and ORC Macro (2003), Statistics Indonesia and Macro International (2008), and BKKBN et al. (2018)

In 1997, the mean duration of breastfeeding among women in NTT was 10.3 months, while the TFR was 3.45. In 2002/2003, the mean duration reached a peak of 10.8 months. However, the TFR also increased to 4.1. In the following years, when the duration of breastfeeding was shorter, on the contrary, the TFR continued to increase and hit 4.2 before decreasing to 3.4 at the end of the period. The mean duration of sexual abstinence after a child's birth and TFR in NTT had also shown a similarity. In 1997-2002 and 20122017, the increase of the mean duration of sexual abstinence was followed by a rise in TFR. That is, the mean duration of sexual abstinence and TFR had a positive correlation. However, from 2007 to 2012, postpartum abstinence correlated negatively with TFR. While postpartum abstinence increased from 4.1 to 4.6 months, TFR dropped significantly from 4.2 to 3.3 births per woman. Therefore, it can be argued that the duration of postpartum amenorrhea and postpartum abstinence among women in NTT had likely been not associated with the stalled fertility decline in the studied region as the data shown in the Indonesia DHS depicts mix trends of the correlation between postpartum infecundability and TFR over the past two decades.

\section{CONCLUSIONS}

This study aimed to investigate the indirect and direct determinants of stalled fertility decline in NTT, Indonesia, between 2002 and 2017. The main findings in this study revealed that all indirect determinants of fertility -culture, socioeconomics, and governanceshaped women's persistent fertility behaviour in NTT. Meanwhile, among three direct determinants of fertility -contraception, marriage, and postpartum infecundability- only contraception was largely responsible for the stall in this province during the period.

Regarding marriage, even though the median age at first marriage among women in NTT was higher than the other provinces in Indonesia, it was not associated with TFR as the increasing trend of the median age being different with changing trend of TFR in this province over the period. This pattern was also similar to the association between postpartum infecundability and TFR. Meanwhile, contraceptive use was the main explanation for TFR in the studied region during the time. Among provinces in Indonesia, the supply and demand sides of contraceptive use in NTT were the poorest. On the demand side, it was shaped by persistent cultural factors and poor socio-economic conditions. The supply side was driven by the poor performance of the government in promoting relevant anti-natalist policies.

Therefore, the role of government in addressing this issue is crucial. From the supply side, the government needs to boost contraception provision in this province and make it affordable and accessible by couples. Moreover, due to demographic affairs, including fertility, not being strategic enough from politicians and public servants to be put into the mainstream of development at the local level, each regency and municipality in NTT needs to be given sufficient incentives to lower its TFR. For instance, extra funds 
can be given to regencies when completing their target in decreasing TFR.

Meanwhile, to promote individuals' attitudes (in the demand side) toward lower fertility, the government needs to promote the quality of female education and boost the provision of information regarding the negative outcome of having many children and how to use contraception effectively. Other than that, incentives to have fewer children need to be provided. The government can integrate bonuses of having fewer children with other social benefits provided recently. By conducting these policies, NTT might accelerate its fertility decline until reach the replacement level so that society's wellbeing in this province might be better off.

\section{ACKNOWLEDGEMENTS}

The author would like to thank Dr Iwu Utomo -the lecturer in the School of Demography, Australian National University- and Professor Ian Thynne -the lecturer in the Crawford School of Public Policy, Australian National University- who influenced the topic of this study, and always provided academic guidance and feedback.

\section{REFERENCES}

Abbasi-Shavazi, M. J., McDonald, P., \& HosseiniChavoshi, M. (2009). The fertility transition in Iran: Revolution and reproduction (1st ed.). Springer Netherlands. https://doi.org/ 10.1007/978-90-481-3198-3

Atieno, F. F. (2012). Proximate determinants of fertility: A comparative study of Western and Central provinces, Kenya [Masters Thesis, University of Nairobi]. University of Nairobi Research

Archive. http://erepository.uonbi.ac.ke:8080/xmlui/han dle/123456789/11391

Birdsall, N., \& Sinding, S. W. (2001). How and why population matters: New findings, new issues. In N. Birdsall, A. C. Kelley, \& S. W. Sinding (Eds.), Population matters: Demographic change, economic growth, and poverty in the developing world (pp. 3-23). Oxford University Press. https://doi.org/10.1093/0199244073.003.0001
BKKBN, Statistics Indonesia, Ministry of Health (Kemenkes), \& ICF. (2018). Indonesia Demographic and Health Survey 2017.

Bongaarts, J. (1978). A framework for analysing the proximate determinants of fertility. Population and Development Review, 4(1), 105-132. http://www.jstor.org/stable/1972149

Bongaarts, J. (1982). The fertility-inhibiting effects of the intermediate fertility variables. Studies in Family Planning, 13(6/7), 179-189. https://doi.org/10.2307/1965445

Bongaarts, J., \& Sobotka, T. (2012). A demographic explanation for the recent rise in European fertility. Population and Development Review, 38(1), $83-120$. https://www.jstor.org/stable/41857358

Bowen, G. A. (2009). Document analysis as a qualitative research method. Qualitative Research Journal, 9(2), 27. https://doi.org/10.3316/QRJ0902027

Bria, E. I. (2014). Hubungan peran tenaga kesehatan dalam memberikan konseling KB dengan penggunaan alat kontrasepsi pada wanita pasangan usia subur di Puskesmas Rafae, Kabupaten Belu, Nusa Tenggara Timur. Jurnal Keperawatan Fakultas Keperawatan, 2, 1-9. http://www.journal.unair.ac.id/downloadfullpapers-pmnjabc42a0634full.docx

Cammack, M., \& Heaton, T. B. (2001). Regional variation in acceptance of Indonesia's family planning program. Population Research and Policy Review, 20(6), 565-585. https://doi.org/10.1023/A:1015659123964

Casterline, J. B. (2001). Diffusion processes and fertility transition: Introduction. In Diffusion processes and fertility transition: Selected perspectives (pp. 1-38). National Academies Press https://www.ncbi.nlm.nih.gov/books/NBK223 $862 /$

Easterlin, R. A. (1975). An economic framework for fertility analysis. Studies in Family Planning, 6(3), 54-63. https://doi.org/10.2307/1964934

Ezeh, A. C., Mberu, B. U., \& Emina, J. O. (2009). Stall in fertility decline in Eastern African countries: Regional analysis of patterns, determinants and implications. Philosophical Transactions of the Royal Society B: Biological Sciences, 364(1532), 2991-3007. 10.1098/rstb.2009.0166 
Fillaili, R., \& Mawardi, S. (2006). The practice of belis tradition in NTT society. In L. Hadiz (Ed.), SMERU Newsletter No. 20: Oct-Dec. The SMERU Research Institute. http://www.smeru.or.id/sites/default/files/publ ication/news20.pdf

Gietel-Basten, S. (2018). Fertility decline. In Z. Zhao \& A. C. Hayes (Eds.), Routledge Handbook of Asian Demography (pp. 64-86). Routledge.

Hull, T. H. (1987). Fertility decline in Indonesia: An institutionalist interpretation. International Family Planning Perspectives, 13(3), 90-95. https://doi.org/10.2307/2947904

Hull, T. H., Raharto, A., Handayani, T., Setiawan, B., \& Noveria, M. (1999). Family planning and family decision-making in Nusa Tenggara Timur. Center for Population and Manpower Studies, Indonesian Institute of Sciences.

Hull, T. H. (2007). Formative years of family planning in Indonesia. In W. C. Robinson \& J. A. Ross (Eds.), The global family planning revolution: Three decades of population policies and programs (pp. 235-256). The World Bank. https://openknowledge.worldbank.org/handle/ $10986 / 6788$

Hull, T. H., \& Hartanto, W. (2009). Resolving contradictions in Indonesian fertility estimates. Bulletin of Indonesian Economic Studies, 45(1), 61-71. https://doi.org/10.1080/00074910902836197

Hull, T. H., \& Mosley, W. H. (2009). Revitalisation of Family Planning in Indonesia. The Government of Indonesia and the United Nations Population Fund. https://www.researchgate.net/publication/2653 96314_Revitalization_of_Family_Planning_in _Indonesia

Jatmiko, Y. A., \& Wahyuni, S. (2019). Determinan fertilitas di Indonesia hasil SDKI 2017. Euclid, $6(1)$, 95-106. https://doi.org/10.33603/e.v6i1.1516

Koten, P. P. (2015). The social context of Lamaholots' fertility desires [Doctor of Philosophy, Monash University]. https://aueast.erc.monash.edu.au/fpfiles/16418465/4719 787_monash_165989.pdf

Kreider, A., Shapiro, D., Varner, C., \& Sinha, M. (2009, September 27 - October 2). Socioeconomic progress and fertility transition in the developing world: Evidence from the
Demographic and Health Surveys [Paper presentation]. International Union for the Scientific Study of Population International Population Conference, Marrakesh, Morocco.

Kumar, S. (2016). The Causes of Indonesia's late fertility transition stall [Masters Thesis, Cornell University]. eCommons. https://doi.org/10.7298/X4FQ9TJ2

Kurniawan, R. (2019). Determinants of the dowry: Finding from IFLS Eastern Indonesia. Jurnal DINAMIKA Ekonomi Pembangunan, 2(2), 7179.

https://logovcelebes.id/publikasi/artikel/item/6 5-determinants-of-the-dowry-finding-fromifls-eastern-indonesia

Majumder, N., \& Ram, F. (2015). Explaining the role of proximate determinants on fertility decline among poor and non-poor in Asian countries. PLOS ONE, 10(2), e0115441. https://doi.org/10.1371/journal.pone.0115441

McDonald, P. (2000). Gender equity in theories of fertility transition. Population and Development Review, 26(3), 427-439. https://doi.org/10.1111/j.17284457.2000.00427.x

McDonald, P., \& Moyle, H. (2010). Why do Englishspeaking countries have relatively high fertility? Journal of Population Research, 27(4),

247-273. https://doi.org/10.1007/s12546-010-9043-0

Murigi, M. N. (2016). Socio-economic and Demographic Determinants of Fertility in North Eastern Kenya [Masters Thesis, University of Nairobi]. Erepository. http://erepository.uonbi.ac.ke/bitstream/handle /11295/98794/Murigi_Socioeconomic\%20and \%20Demographic\%20Determinants \%20of\%2 0Fertility\%20in\%20North\%20Eastern $\% 20 \mathrm{Ke}$ nya.pdf? sequence $=1 \&$ is Allowed $=\mathrm{y}$

Oktriyanto, O. (2016). Penyelenggaraan pelayanan Keluarga Berencana dalam Jaminan Kesehatan Nasional. Jurnal Ilmu Keluarga \& Konsumen, 9(2), 77-88. https://doi.org/10.24156/jikk.2016.9.2.77

Permana, I. B., \& Westoff, C. F. (1999). The two-child norm in Indonesia. DHS Further Analysis Reports No. 28. Macro International. https://dhsprogram.com/publications/publicati on-fa28-further-analysis.cfm 
Preston, S., Heuveline, P., \& Guillot, M. (2000). Demography: Measuring and modeling population processes. Blackwell Publishing Ltd.

Rahmadewi, R., \& Asih, L. (2011). Tingkat fertilitas di Provinsi Nusa Tenggara Timur dan Yogyakarta. Kesmas: National Public Health Journal, 6(3), 117-125. https://doi.org/10.21109/kesmas.v6i3.102

Rahman, M. M. (2019). Role of proximate determinants in recent and past fertility stalls in Bangladesh. Biodemography and Social Biology, 65(2), 119-136. https://doi.org/10.1080/19485565.2019.16837 13

Ritonga, R. (2015, February 24-25). Kebutuhan data ketenagakerjaan untuk pembangunan berkelanjutan [Paper presentation]. The Economic and Social Council 2015 Integration Segment - "Achieving sustainable development through employment creation and decent work for all": Indonesia country-level consultation, Jakarta, Indonesia.

Rodliyah, S., Purwasito, A., Sudardi, B., \& Abdullah, W. (2016). Belis and the perspective of dignified women in the marital system of East Nusa Tenggara (NTT) people. Jurnal of Education and Social Science, 5(2). https://www.jesoc.com/wpcontent/uploads/2016/12/KC5_11.pdf

Rutaremwa, G., Galande, J., Nviiri, H. L., Akiror, E., \& Jhamba, T. (2015). The contribution of contraception, marriage and postpartum insusceptibility to fertility levels in Uganda: An application of the aggregate fertility model. Fertility Research and Practice, 1(1), 16. https://doi.org/10.1186/s40738-015-0009-y

Seiff, A. (2014). Indonesia to revive national family planning programme. The Lancet, 383(9918), $683 . \quad$ https://doi.org/10.1016/S01406736(14)60244-0

Setiawan, B. (2005). Barriers to male participation in family planning in West Timor. Asia-Pacific Population Journal, 19(4), 55-74. https://www.un-

ilibrary.org/content/journals/15644278/19/4/7

Sibanda, A., Woubalem, Z., Hogan, D. P., \& Lindstrom, D. P. (2003). The proximate determinants of the decline to below replacement fertility in Addis Ababa, Ethiopia.
Studies in Family Planning, 34(1), 1 - 7. https://doi.org/10.1111/j.17284465.2003.00001.x

Statistics Indonesia. (1984). Fertility and mortality estimates based on 1971 and 1980 Population Censuses.

Statistics Indonesia. (2018). Statistical yearbook of Indonesia 2018. https://www.bps.go.id/publication/2018/07/03 15a963c1ea9b0fed6497d0845/statistikindonesia-2018.html

Statistics Indonesia, BKKBN, \& IRD. (1989). Indonesia National Contraceptive Prevalence Survey 1987. https://dhsprogram.com/publications/publicati on-fr19-dhs-finalreports.cfm?cssearch=235995_1

Statistics Indonesia, BKKBN, Kementerian Kesehatan (Kemenkes-MOH), \& ICF International. (2013). Indonesia Demographic and Health Survey 2012. https://dhsprogram.com/publications/publicati on-fr275-dhs-final-reports.cfm

Statistics Indonesia, BKKBN, Ministry of Health, \& Macro Intemational Inc. (1992). Indonesia Demographic and Health Survey 1991. https://dhsprogram.com/publications/publicati on-fr18-dhs-finalreports.cfm?cssearch=235995_1

Statistics Indonesia, BKKBN, Ministry of Health, \& Macro Intemational Inc. (1995). Indonesia Demographic and Health Survey 1994. https://dhsprogram.com/publications/publicati on-fr63-dhs-finalreports.cfm?cssearch=235995_1

Statistics Indonesia, BKKBN, Ministry of Health, \& Macro Intemational Inc. (1998). Indonesia Demographic and Health Survey 1997. https://dhsprogram.com/publications/publicati on-fr95-dhs-finalreports.cfm?cssearch=235995_1

Statistics Indonesia, \& Macro International. (2008). Indonesia Demographic and Health Survey 2007.

https://dhsprogram.com/publications/publicati on-fr218-dhs-finalreports.cfm?cssearch $=235995 \_1$

Statistics Indonesia, \& ORC Macro. (2003). Indonesia demographic and health survey 2002-2003. https://dhsprogram.com/publications/publicati 
on-fr147-dhs-final-

reports.cfm?cssearch=235995_1

Statistics of NTT Province. (2017). East Nusa Tenggara Province in Figures 2017. https://ntt.bps.go.id/publication/2017/08/11/d2 bad335b43219f7f2983f31/provinsi-nusatenggara-timur-dalam-angka-2017.html

Tey, N. P., Ng, S. T., \& Yew, S. Y. (2012). Proximate determinants of fertility in Peninsular Malaysia. Asia Pacific Journal of Public Health, 24(3), 495-505. https://doi.org/10.1177/101053951140137 4

United Nations, Department of Economic and Social Affairs, Population Division. (2014). World Fertility Report 2013: Fertility at the extremes. United Nations Publications. https://www.un.org/en/development/desa/pop ulation/publications/pdf/fertility/worldFertility Report2013.pdf

Weeks, J. R. (2008). Population: An introduction to concepts and issues (10th ed.). Wadsworth.

Wonga, I. (2017, July 7). Mahalnya Mahar Nikah di NTT, Mulai dari Gading hingga Uang Puluhan Juta. Pos Kupang. https://kupang.tribunnews.com/2017/07/07/ma halnya-mahar-nikah-di-ntt-mulai-dari-gadinghingga-uang-puluhan-juta

Zhao, E. Z., \& Hayes, A. C. (Eds.). (2018). Routledge Handbook of Asian Demography. Routledge. 
Jurnal Kependudukan Indonesia | Vol. 15, No. 2, Desember 2020 |227-244 